\title{
Rancang Bangun Pengendali Sistem Pompa Otomatis Pada Penyiraman Tanaman Berbasis Sensor Kelembaban dengan Kendali Arduino
}

\author{
Antonius Rajagukguk \\ Departemen Teknik Elektro, \\ Fakultas Teknik, \\ Universitas Riau \\ antonius.rajagukguk@lecturer.unri \\ .ac.id
}

\author{
Joel Fernando Simamora \\ Departemen Teknik Elektro, \\ Fakultas Teknik, \\ Universitas Riau \\ joel.fernandosimamora@student.u \\ nri.ac.id
}

\author{
Edy Ervianto \\ Departemen Teknik Elektro, \\ Fakultas Teknik \\ Universitas Riau \\ edy.ervianto@eng.unri.ac.id
}

\begin{abstract}
Along with technological advances in modern times, and the development of science, human needs are also growing. In order to facilitate human work, many technologies have been created using automatic systems. One of them is in the case of automatic plant watering for farmers or garden owners. For this reason, the authors carried out a design of automatic plant sprinklers based on the YL-38 type soil moisture sensor which will be controlled by Arduino. Which later will send a duty cycle to the buck converter to change the voltage automatically according to soil conditions which have been grouped into four parts, namely very dry, dry, humid, and wet. Changes in voltage will affect the rotational speed of the motor according to the needs of the ground. With real time watering, the RTC DS1302 type is used so that this watering will be more scheduled. This watering uses a supply from a 12 volt DC battery with a 12 volt water pump motor load.
\end{abstract}

Keywords : duty cycle, buck converter, arduino, soil moisture sensor.

\section{PENDAHULUAN}

Pengaturan otomatis atau sistem pengaturan otomatis berasal dari tiga suku kata yaitu sistem, pengaturan dan otomatis. Sistem adalah sebuah susunan komponen-komponen fisik yang saling terhubung dan membentuk satu kesatuan untuk melakukan aksi tertentu. Pengaturan adalah suatu aktivitas mengatur,mengendalikan, mengarahkan, memerintah. Sedangkan otomatis adalah dengan bekerja sendiri atau dengan sendirinya. Dalam hal ini istilah pengaturan atau kontrol mengandung tiga aspek atau unsur utama yaitu rencana yang jelas, dapat melakukan pengukuran, dan dapat melakukan tindakan. Dari pengertian tersebut, kita dapat menganggap kontrol atau pengaturan otomatis yang dimaksud adalah "Membuat sesuatu sesuai dengan harapan ataupun rencana kita dan juga berjalan dengan sendirinya tanpa campur tangan manusia secara langsung". maka kita dapat menganggap suatu sistem kontrol otomatis adalah suatu sistem yang dapat membuat agar keluaran (output) sistem sesuai dengan rencana dan keinginan yang diharapkan [1].
Otomatisasi adalah proses untuk mengontrol operasi dari suatu alat secara otomatis yang dapat mengganti peran manusia untuk mengamati dan mengambil keputusan. Sistem kontrol yang ada saat ini mulai bergeser pada otomatisasi sistem kontrol, sehingga campur tangan manusia dalam pengontrolan sangat kecil. Sistem peralatan yang dikendalikan secara otomatis sangat memudahkan apabila dibandingkan dengan sistem manual, karena lebih efisien, aman, dan teliti. Seiring dengan kemajuan teknologi di zaman yang modern ini, dan berkembangnya ilmu pengetahuan, maka kebutuhan manusiapun semakin berkembang. Guna mempermudah kinerja manusia, telah banyak teknologi yang diciptakan dengan menggunakan sistem otomatis, salah satunya adalah pompa air. Untuk itu dibutuhkan peralatan yang mampu bekerja secara otomatis salah satunya sensor kelembaban [2].

Sensor kelembaban tanah sebagai pendeteksi intensitas air di dalam tanah yang berupa sensor analog dan output yang dihasilkan berupa tegangan 0maksimum. Pengujian kinerja sensor dilakukan dengan memasangkan langsung sensor kelembaban tanah pada media tanaman, respon sensor terhadap kenaikan dan penurunan kelembaban dikirim ke kontroler. Kelebihan alat ini dapat memberikan respon keluaran berupa kenaikan dan penurunan kelembaban dari tanah. Sehingga keluaran dari sensor ini akan direspon oleh kontroler untuk menghidupkan atau mematikan pompa [3].

Kontroler yang dipakai salah satunya arduino yang merupakan pengendali mikro single board yang bersifat open-source, diturunkan dari wiring platform dan dirancang untuk memudahkan pengguna elektronik dalam berbagai bidang. Keluaran dari kontroler akan dikirimkan ke buck converter untuk mengatur kecepatan motor. Sehingga debit air yang dikeluarkan motor sesuai dengan keperluan tanaman yang telah dibaca kondisi tanahnya oleh sensor kelembaban. Pada alat ini menghasilkan 4 kriteria kondisi tanah yaitu tanah basah, lembab, kering, dan sangat kering. Namun alat hanya akan bekerja pada kondisi tanah lembab, 


\section{Rancang Bangun Pengendali Sistem Pompa Otomatis Pada Penyiraman Tanaman Berbasis Sensor Kelembaban dengan Kendali Arduino}

kering dan sangat kering, apabila kondisi tanah basah maka motor tidak bekerja [4]

Buck converter adalah dc-dc converter jenis penurun tegangan atau step down. Buck converter mampu menghasilkan nilai tegangan output sama atau lebih rendah dari tegangan input-nya. Buck converter dapat menurunkan tegangan tanpa membutuhkan trafo. Karena hanya menggunakan satu buah semikonduktor, buck converter memiliki efisiensi yang tinggi. Kemudian keluaran dari buck converter masuk ke motor pompa yang mampu mengubah tegangan sehingga keluaran air pada motor pompa dapat diatur [5].

Pada motor pompa, jenis yang digunakan adalah motor pompa DC. Prinsip kerja pompa adalah menghisap dan melakukan penekanan terhadap fluida. Pada sisi hisap pompa atau biasa disebut suction, elemen pompa akan menurunkan tekanan dalam ruang pompa sehingga akan terjadi perbedaan tekanan antara ruang pompa dengan permukaan fluida dihisap. Dengan demikian fluida akan mengalir ke ruang pompa. Oleh elemen pompa fluida ini akan didorong dan diberikan tekanan sehingga fluida akan mengalir kedalam saluran tekan (discharge) melalui lubang tekan. Klasifikasi pompa menurut prinsip dan cara kerjanya dapat diklasifikasikan menjadi 2 yaitu pompa kerja positif (positive displacement pump) dan pompa kerja dinamis [6], [7].

Berdasarkan pemaparan diatas, penulis tertarik melakukan penelitian tentang penyiraman tanaman otomatis menggunakan motor DC dengan kendali arduino. Penggunaan motor DC efektif karena hanya mengatur variable tegangan motor untuk mengubah kecepatan motor sehingga air yang diberikan sesuai dengan kondisi tanah. Alat ini diharapkan dapat membantu manusia dalam merawat tanaman dan menjaga tanaman dapat tumbuh dengan subur.

\section{TEORI DASAR}

A. Sensor Kelembaban Tanah

Soil moisture sensor merupakan sensor yang mampu mendeteksi intensitas air didalam tanah yang berupa sensor analog dimana output yang dihasilkan berupa tegangan 0-maksimum. Ketika sensor bekerja, maka sensor akan mulai mendeteksi kadar air dalam tanah apakah dalam keadaan kering atau basah (lembab). Sensor akan dipasangkan langsung ke media tanaman, kemudian respon sensor terhadap kenaikan dan penurunan kelembaban akan dikirim ke controller [8].

\section{B. Buck Converter}

Buck converter adalah salah satu jenis dari konverter yang dapat mengubah tegangan DC pada nilai tertentu menjadi tegangan DC yang lebih rendah tegangan inputnya. Tegangan pada beban adalah hasil dari pembagian durasi menyala dan padamnya saklar (duty cycle) dari tegangan input, sehingga tegangan keluaran buck converter menjadi lebih rendah dari pada tegangan masukannya [8].

$$
\mathrm{V}_{\mathrm{O}}=\mathrm{V}_{\mathrm{S}} \times \mathrm{D}
$$

\section{Pulse With Modulation (PWM)}

Dapat diartikan bahwa PWM memiliki nilai frekuensi yang tetap namun nilai duty cycle bervariasi. Duty cycle merupakan kondisi sinyal logika high dan sinyal logika low dalam suatu periode dinyatakan dalam bentuk persen (\%) dengan range 0\% sampai 100\% [10].

\section{METODE}

Dalam melakukan rancang bangun alat maka dibutuhkan perancangan rakitan, pengukuran, dan pengujian. Berikut merupakan alur penelitian yang dilakukan.

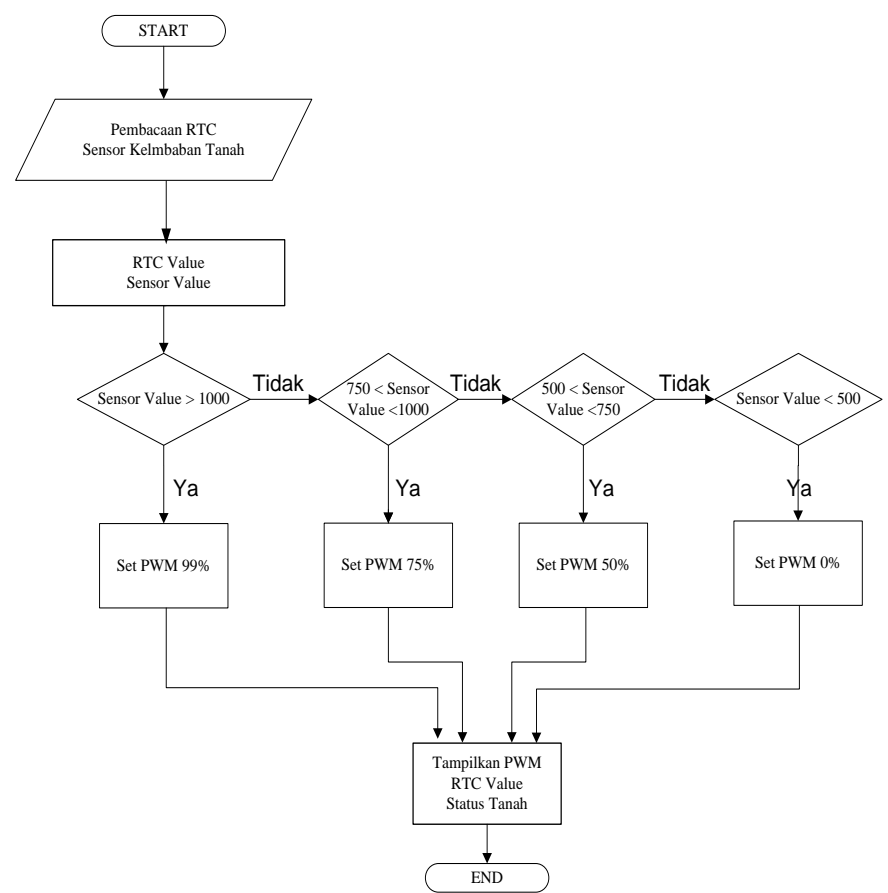

Gambar 1. Flowchart

Pada proses pemerograman pada modul mikrokontroler yang dibutuhkan pada sistem ini yaitu Arduino Uno yang digunakan untuk membuat program serta melakukan kontrol. Berikut tampilan program yang diterapkan :

\#include <Wire.h>

\#include <virtuabotixRTC.h>

\#include <LiquidCrystal_I2C.h>

LiquidCrystal_I2C lcd(0x27,20,4);

//inisialisasi pin (CLK, DAT, RST)

virtuabotixRTC myRTC $(6,7,8)$;

int sensorPin $=\mathrm{A} 0$;

int sensorValue $=1014$;

const int $\mathrm{PWM}=9$;

void $\operatorname{setup}()\{$

Serial.begin(9600);

lcd.init();

lcd.init(); 


\section{Rancang Bangun Pengendali Sistem Pompa Otomatis Pada Penyiraman Tanaman Berbasis Sensor Kelembaban dengan Kendali Arduino}

lcd.backlight();

pinMode(PWM, OUTPUT);

myRTC.setDS1302Time(00,00,07,6,20,10,2020);

TCCR1B $=($ TCCR1B\&0b11111000 $) \mid 3 ; / /$ menseting register arduino untuk menggunakan timer $1500 \mathrm{~Hz}$

while(!Serial);

\}

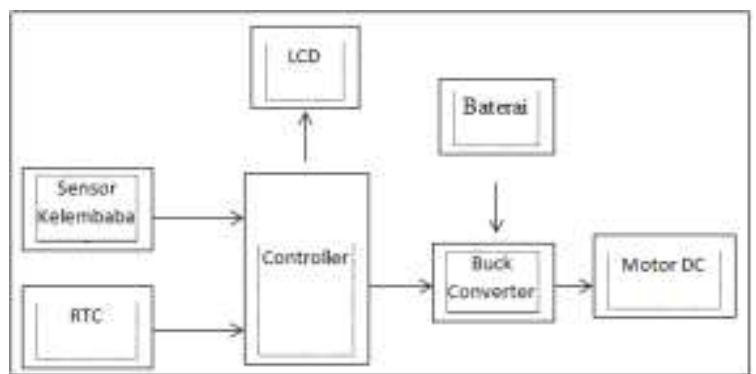

Gambar 2. Blok Diagram Rancang Bangun

Blok diagram yang ditunjukan dari gambar 2 diatas merupakan gambaran dari perancangan sistem yang diteliti. Adapun penjelasan blok diagram diatas sebagai berikut:

1. Sensor kelembaban dan RTC digunakan sebagai input kontroler, sensor kelembaban digunakan sebagai pengukur intensitas kelembaban tanah dan RTC sebagai penunjuk waktu secara real time.

2. Setelah sistem aktif maka sensor kelembaban tanah akan membaca kadar intensitas air yang ada dalam tanah, yang kemudian hasil pembacaannya akan di biaca oleh arduino.

3. Arduino sebagai controller akan mengolah hasil pembacaan sensor yang kemudian ditampilkan pada LCD.

4. Kemudian arduino akan bekerja untuk mengontrol buck converter untuk menyalurkan tegangan sesuai kriteria kondisi tanah kepada motor pompa. Sehingga suplai yang diberikan batrai akan berubah tegangannya sesuai kebutuhan kondisi tanah, yang kemudian motor akan berubah kecepatannya sesuai dengan kondisi tanah.

Dalam melakukan perancangan buck converter, terlebih dahulu dilakukan pengukuran dalam komponen yang ada yaitu, induktor, kapasitor, dan resistor.

Berikut nilai resistor :

$$
\begin{gathered}
\mathrm{P}=\frac{\mathrm{V}^{2}}{\mathrm{R}} \\
\mathrm{R}=\frac{\mathrm{V}^{2}}{\mathrm{P}} \\
\mathrm{R}=\frac{12^{2}}{65}=2,2 \Omega
\end{gathered}
$$

Berikut nilai induktor yang digunakan :

$$
\mathrm{L}_{\min }=\frac{(1-\mathrm{D}) \mathrm{R}}{2 \mathrm{f}}
$$

Digunakan nilai induktor dengan duty cycle $10 \%$. Maka,

$$
\begin{gathered}
\mathrm{L}=\frac{(1-0.10) 2,2}{2.500} \\
\mathrm{~L}=1980 \mu \mathrm{H} .
\end{gathered}
$$

Induktor dengan nilai duty cycle 50\%.

$$
\begin{gathered}
\mathrm{L}=\frac{(1-0.50) 2,2}{2.500} \\
\mathrm{~L}=1100 \mu \mathrm{H}
\end{gathered}
$$

Induktor dengan nilai duty cycle $75 \%$.

$$
\begin{gathered}
\mathrm{L}=\frac{(1-0.75) 2,2}{2.500} \\
\mathrm{~L}=550 \mu \mathrm{H}
\end{gathered}
$$

Sedangkan induktor dengan nilai duty cycle $99 \%$.

$$
\begin{gathered}
L=\frac{(1-0.99) 2,2}{2.500} \\
L=22 \mu \mathrm{H}
\end{gathered}
$$

Berdasarkan hasil perhitungan diatas, maka rating induktor yang digunakan besar dari $1980 \mathrm{uH}$ atau $1,9 \mathrm{mH}$. Sehingga rating induktor yang digunakan pada penelitian ini adalah $2,1 \mathrm{mH}$.

Berikut nilai kapasitor yang digunakan :

$$
C=\frac{1-D}{8 \cdot L \cdot V_{r} \cdot f^{2}}
$$

Nilai kapasitor dengan duty cycle $10 \%$.

$$
\mathrm{C}=\frac{(1-0,10) 1,2}{8 \cdot 0,24,0,00198.500^{2}} .
$$

Nilai kapasitor dengan duty cycle 50\%.

$$
\mathrm{C}=\frac{[1-0,5] 6}{\mathrm{~B} .0,240,0011.500^{2}} .
$$

Nilai kapasitor dengan duty cycle $75 \%$.

$$
\begin{gathered}
\mathrm{C}=\frac{[1-0,5] 6}{8.0,240,00055.500^{2} .} \\
\mathrm{C}=8522 \mathrm{u}
\end{gathered}
$$

Nilai kapasitor dengan duty cycle $99 \%$.

$$
\mathrm{C}=\frac{[1-0,5] 6}{8.0,24,0,000022.500^{2}} .
$$

Berdasarkan hasil perhitungan diatas, maka rating kapasitor yang digunakan besar dari 11250uf atau $11,25 m f$. Sehingga rating kapasitor yang digunakan pada penelitian ini adalah $14100 u f$.

Metode sensing pada penelitian ini menggunakan sensor kelembaban tanah dengan tipe YL-38. Setelah 


\section{Rancang Bangun Pengendali Sistem Pompa Otomatis Pada Penyiraman Tanaman Berbasis Sensor Kelembaban dengan Kendali Arduino}

teruji sensor ini mampu mengukur intensitas air dalam tanah dan juga penggunaannya lebih sederhana. Sensor kelembaban dapat dilihat pada Gambar 3 .

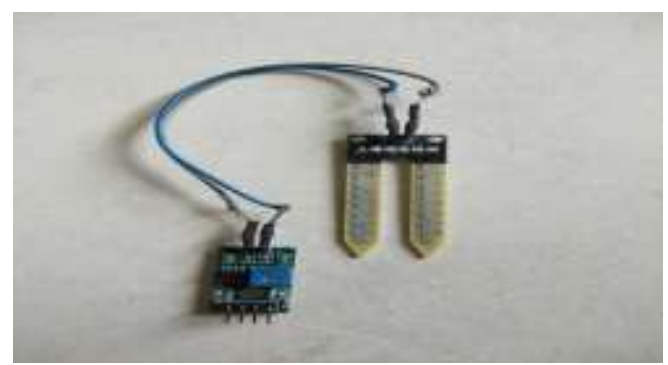

Gambar 3. Sensor kelembaban tanah type YL-38

Pada penelitian ini motor pompa yang akan digunakan adalah motor pompa air DC dengan tegangan masukan sebesar 12 volt. Pompa dihubugkan secara langsung pada keluaran dari buck converter. Motor pompa DC yang digunakan pada penelitian ini dapat dilihat pada Gambar dibawah ini.

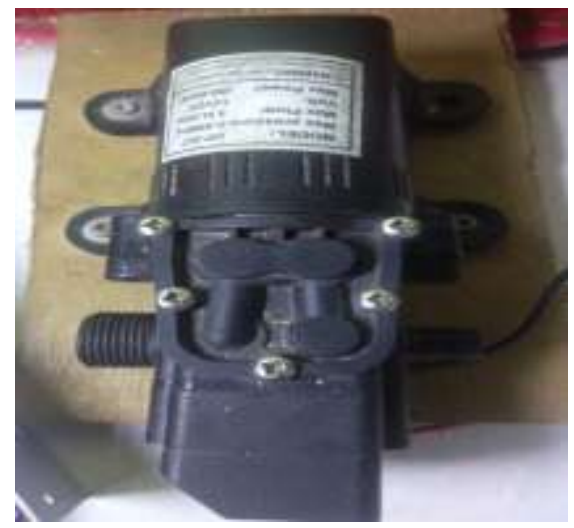

Gambar 4. Motor Pompa Air DC 12 volt

\section{HASIL DAN PEMBAHASAN}

\section{A. Topologi Sistem}

Terdapat beberapa komponen yang diperlukan untuk merancang sistem agar mampu melakukan tugas sebagai penyiraman tanaman otomatis seperti yang diharapkan.

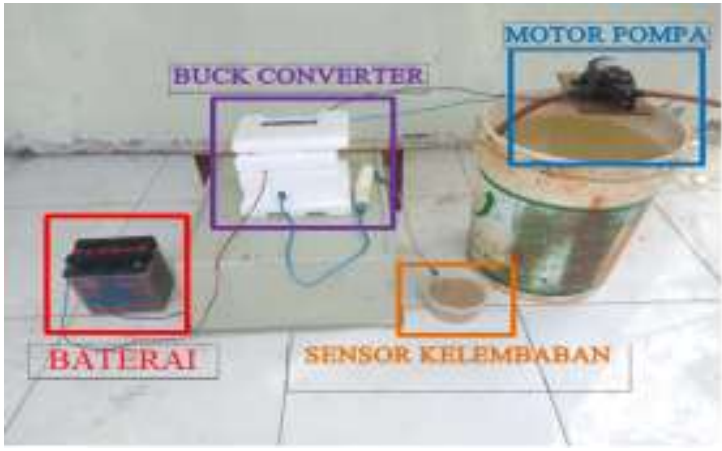

Gambar 5. Topologi Sistem

\section{B. Studi Kasus Keadaan Sangat Kering}

Pada pengujian ini diterapkan pada tanah yang intensitas air nya sangat kering, dengan mengasumsikan nilai sensor 1000 sampai 1023.

Tabel 1. Nilai Output Converter Terhadap Kondisi Tanah Sangat Kering (Tanpa Beban)

\begin{tabular}{|c|c|c|c|c|c|}
\hline Hari & Jam & Sensor & $\begin{array}{l}\text { Status } \\
\text { Tanah } \\
\end{array}$ & $\begin{array}{l}\text { Vin } \\
\text { (V) }\end{array}$ & $\begin{array}{c}\text { Vout } \\
(\mathrm{V}) \\
\end{array}$ \\
\hline \multirow{2}{*}{1} & 07.00 & 1014 & $\begin{array}{l}\text { Sangat } \\
\text { Kering }\end{array}$ & 12 & 11.8 \\
\hline & 17.00 & 1019 & $\begin{array}{l}\text { Sangat } \\
\text { Kering }\end{array}$ & 12 & 11.8 \\
\hline \multirow{2}{*}{2} & 07.00 & 1011 & $\begin{array}{l}\text { Sangat } \\
\text { Kering }\end{array}$ & 12 & 11.8 \\
\hline & 17.00 & 1018 & $\begin{array}{l}\text { Sangat } \\
\text { Kering }\end{array}$ & 12 & 11.8 \\
\hline \multirow{2}{*}{3} & 07.00 & 1012 & $\begin{array}{l}\text { Sangat } \\
\text { Kering }\end{array}$ & 12 & 11.8 \\
\hline & 17.00 & 1022 & $\begin{array}{l}\text { Sangat } \\
\text { Kering }\end{array}$ & 12 & 11.8 \\
\hline \multirow{2}{*}{4} & 07.00 & 1016 & $\begin{array}{l}\text { Sangat } \\
\text { Kering }\end{array}$ & 12 & 11.8 \\
\hline & 17.00 & 1017 & $\begin{array}{l}\text { Sangat } \\
\text { Kering }\end{array}$ & 12 & 11.8 \\
\hline
\end{tabular}

Pada tabel 2 dapat dilihat bahwa tegangan output pada kondisi sangat kering tidak berubah jauh, namun karena pengukuran ini dilakukan tanpa beban maka tidak terdapat arus pada input dan output, begitu juga kecepatan motor.

Tabel 2. Nilai Output Converter Terhadap Kondisi Tanah Sangat Kering (Berbeban)

\begin{tabular}{|c|c|c|c|c|c|c|c|c|}
\hline Hari & Jam & Sensor & $\begin{array}{l}\text { Status } \\
\text { Tanah }\end{array}$ & $\begin{array}{c}\text { Vout } \\
\text { (V) }\end{array}$ & $\begin{array}{l}\text { Iout } \\
\text { (A) }\end{array}$ & $\begin{array}{c}\text { Pout } \\
\text { (W) }\end{array}$ & $\begin{array}{l}\text { Duty } \\
\text { Cycle }\end{array}$ & RPM \\
\hline \multirow[b]{2}{*}{1} & 07.00 & 1014 & $\begin{array}{l}\text { Sangat } \\
\text { Kering }\end{array}$ & 11,7 & 0,3 & 3,5 & $99 \%$ & 3520 \\
\hline & 17.00 & 1019 & $\begin{array}{l}\text { Sangat } \\
\text { Kering }\end{array}$ & 11,8 & 0,3 & 3,5 & $99 \%$ & 3523 \\
\hline \multirow{2}{*}{2} & 07.00 & 1011 & $\begin{array}{l}\text { Sangat } \\
\text { Kering }\end{array}$ & 11,7 & 0,3 & 3,5 & $99 \%$ & 3528 \\
\hline & 17.00 & 1018 & $\begin{array}{l}\text { Sangat } \\
\text { Kering }\end{array}$ & 11,8 & 0,4 & 4,7 & $99 \%$ & 3557 \\
\hline \multirow{2}{*}{3} & 07.00 & 1012 & $\begin{array}{l}\text { Sangat } \\
\text { Kering }\end{array}$ & 11,7 & 0,3 & 3,5 & $99 \%$ & 3519 \\
\hline & 17.00 & 1022 & $\begin{array}{l}\text { Sangat } \\
\text { Kering }\end{array}$ & 11,7 & 0,4 & 4,6 & $99 \%$ & 3527 \\
\hline \multirow{2}{*}{4} & 07.00 & 1016 & $\begin{array}{l}\text { Sangat } \\
\text { Kering }\end{array}$ & 11,7 & 0,3 & 3,5 & $99 \%$ & 3523 \\
\hline & 17.00 & 1017 & $\begin{array}{l}\text { Sangat } \\
\text { Kering }\end{array}$ & 11,8 & 0,4 & 4,7 & $99 \%$ & 3534 \\
\hline
\end{tabular}

Kita lihat bahwa tegangan output tidak jauh dari perhitungan secara teori dengan dutycycle $99 \%$. Arus yang diperoleh rata-rata berkisar 0,38 dengan daya yang dihasilkan rata-rata 4,5 watt. Kecepatan yang 


\section{Rancang Bangun Pengendali Sistem Pompa Otomatis Pada Penyiraman Tanaman Berbasis Sensor Kelembaban dengan Kendali Arduino}

dihasilkan juga tidak berbeda jauh hanya berkisar \pm 3500 RPM.

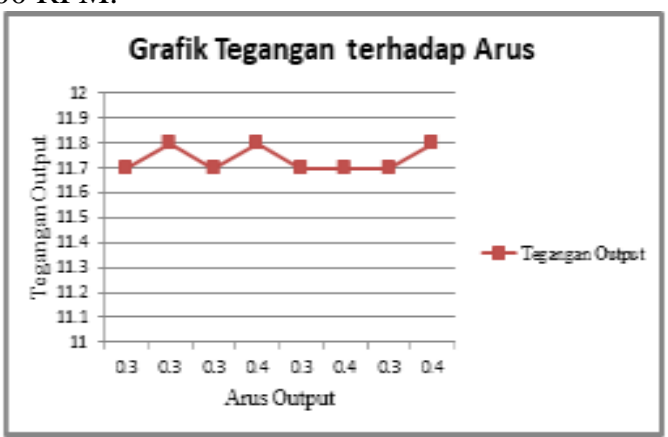

Gambar 6. Grafik Tegangan Terhadap Arus Kondisi Sangat Kering

Berdasarkan grafik pada gambar 6 terlihat bahwa pada arus tertinggi bernilai 0,4 A pada tegangan 4,7 dengan daya 4,7 W menghasilkan putaran motor sebesar 3573 RPM (Rotate Per Minute). Dan arus terendah pada tegangan $11,75 \mathrm{~V}$ dan $11,76 \mathrm{~V}$ dengan putaran motor sebesar 3519 RPM dan 3520 RPM.

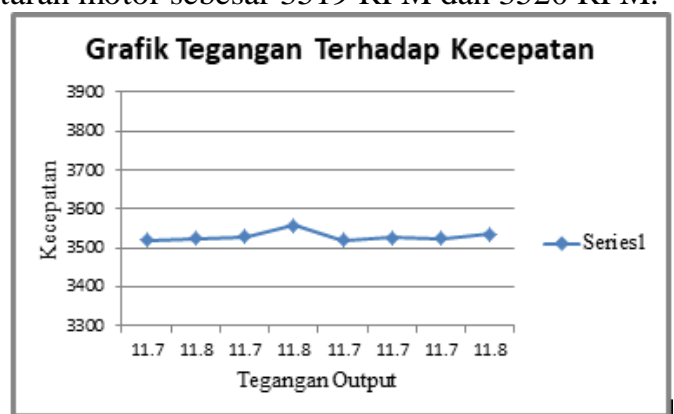

Gambar 7. Grafik Tegangan Terhadap Kecepatan Kondisi Sangat Kering

Berdasarkan gambar 7 pada grafik menunjukkan bahwa kecepatan motor tertinggi ketika keadaan tegangan bernilai 11,77 Volt dengan nilai kecepatan 6657,4 RPM.

\section{Studi Kasus Keadaan Kering}

Pada pengujian ini diterapkan pada tanah yang intensitas air nya kering dengan asumsi nilai sensor 750 sampai 1000, sehingga pada percobaan ini diperoleh hasil keluaran dari pembacaan sistem

Tabel 3. Nilai Output Converter Terhadap Kondisi Tanah Kering (Tanpa Beban)

\begin{tabular}{cccccc}
\hline Hari & Jam & Sensor & $\begin{array}{c}\text { Status } \\
\text { Tanah }\end{array}$ & $\begin{array}{c}\text { Vin } \\
(\mathbf{V})\end{array}$ & $\begin{array}{c}\text { Vout } \\
(\mathbf{V})\end{array}$ \\
\hline \multirow{2}{*}{1} & 07.00 & 940 & Kering & 12 & 9.2 \\
& 17.00 & 963 & Kering & 12 & 9.2 \\
\multirow{2}{*}{2} & 07.00 & 905 & Kering & 12 & 9.2 \\
& 17.00 & 963 & Kering & 12 & 9.2 \\
\multirow{2}{*}{3} & 07.00 & 949 & Kering & 12 & 9.2 \\
& 17.00 & 957 & Kering & 12 & 9.2 \\
4 & 07.00 & 909 & Kering & 12 & 9.2 \\
& 17.00 & 862 & Kering & 12 & 9.2 \\
\hline
\end{tabular}

Pada hasil pengkuran pada tabel 3 dihari pertama pada jam 07.00 dan 17.00 nilai tegangan output bernilai 11,7 dan 11,5. Namun pada hari kedua sampai keempat nilain tegangan output nya hamper sama bahkan lebih besar dari nilai input nya.

Tabel 4. Nilai Output Converter Terhadap Kondisi Tanah Kering (Berbeban)

\begin{tabular}{|c|c|c|c|c|c|c|c|c|}
\hline Hari & Jam & Sensor & $\begin{array}{l}\text { Status } \\
\text { Tanah }\end{array}$ & $\begin{array}{c}\text { Vout } \\
\text { (V) }\end{array}$ & $\begin{array}{l}\text { Iout } \\
\text { (A) }\end{array}$ & $\begin{array}{l}\text { Pout } \\
(\mathrm{W})\end{array}$ & $\begin{array}{l}\text { Duty } \\
\text { Cycle }\end{array}$ & RPM \\
\hline \multirow{3}{*}{1} & 07.00 & 940 & Kering & 9,1 & 0,3 & 2,7 & $75 \%$ & 2641 \\
\hline & & & & & & & & \\
\hline & 17.00 & 963 & Kering & 9,2 & 0,2 & 1,8 & $75 \%$ & 2696 \\
\hline \multirow{2}{*}{2} & 07.00 & 905 & Kering & 9,1 & 0,3 & 2,7 & $75 \%$ & 2638 \\
\hline & 17.00 & 963 & Kering & 9 & 0,3 & 2,7 & $75 \%$ & 2611 \\
\hline \multirow{2}{*}{3} & 07.00 & 949 & Kering & 9,1 & 0,3 & 2,7 & $75 \%$ & 2697 \\
\hline & 17.00 & 957 & Kering & 9,1 & 0,3 & 2,7 & $75 \%$ & 2697 \\
\hline \multirow{2}{*}{4} & 07.00 & 909 & Kering & 9,1 & 0,3 & 2,7 & $75 \%$ & 2689 \\
\hline & 17.00 & 862 & Kering & 9 & 0,3 & 2,7 & $75 \%$ & 2672 \\
\hline
\end{tabular}

Dengan kondisi kering dan penetapan dutycycle di angka $75 \%$, tegangan output yang dihasilkan sesuai yang diharapkan yaitu berkisar $9 \mathrm{~V}$. Arus output yang dihasilkan di rata-rata 0,35 A dengan kecepatan motor rata-rata dinilai 2730 RPM.

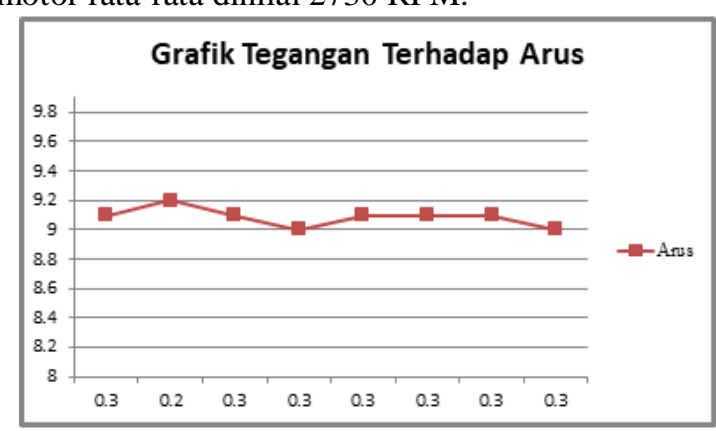

Gambar 8. Grafik Tegangan terhadap Arus Kondisi Kering

Berdasarkan gambar 8 menampilkan grafik dengan arus terendah sebesar 0,34 A pada tegangan 9,42 V, 9,47 V dan 8,56 V. Pada nilai arus tertinggi sebesar 0,36 A terjadi disaat tegangan mencapai 9,04 Volt.

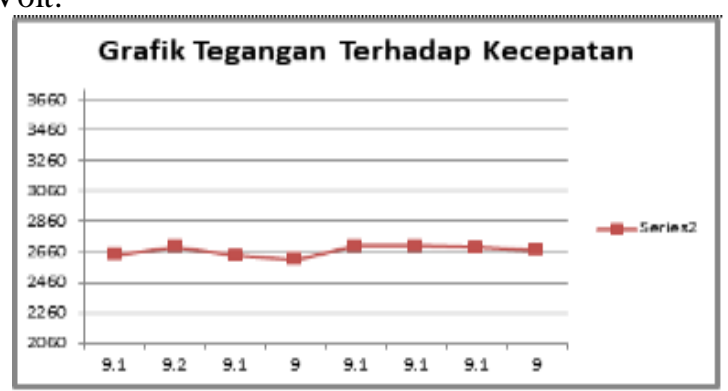

Gambar 9. Grafik Tegangan Terhadap Kecepatan Kondisi Kering 


\section{Rancang Bangun Pengendali Sistem Pompa Otomatis Pada Penyiraman Tanaman Berbasis Sensor Kelembaban dengan Kendali Arduino}

Berdasarkan grafik yang dapat kita lihat pada gambar 9 menyimpulkan bahwa kecepatan tertinggi motor sebesar 2941,4 RPM pada saat tegangan bernilai 9,36 Volt. Sementara kecepatan motor terendah bernilai 2638,6 RPM pada tegangan 9,42 Volt.

\section{Studi Kasus Keadaan Lembab}

Pada pengujian ini diterapkan pada tanah yang intensitas air nya lembab diasumsikan nilai sensor mulai dari 500 sampai 750, sehingga pada percobaan ini diperoleh hasil keluaran dari pembacaan sistem.

Tabel 5. Nilai Output Converter Terhadap Kondisi Tanah Lembab (Tanpa Beban)

\begin{tabular}{cccccc}
\hline Hari & Jam & Sensor & $\begin{array}{c}\text { Status } \\
\text { Tanah }\end{array}$ & $\begin{array}{c}\text { Vin } \\
(\mathbf{V})\end{array}$ & $\begin{array}{c}\text { Vout } \\
(\mathbf{V})\end{array}$ \\
\hline \multirow{2}{*}{1} & 07.00 & 722 & Lembab & 12 & 6.1 \\
& 17.00 & 640 & Lembab & 12 & 6 \\
2 & 07.00 & 716 & Lembab & 12 & 6.2 \\
& 17.00 & 545 & Lembab & 12 & 6.1 \\
3 & 07.00 & 613 & Lembab & 12 & 6.2 \\
& 17.00 & 532 & Lembab & 12 & 6.1 \\
4 & 07.00 & 595 & Lembab & 12 & 6 \\
& 17.00 & 759 & Lembab & 12 & 6.1 \\
\hline \multirow{2}{*}{2}
\end{tabular}

Pada kondisi lembab tanpa berbeban sesuai dengan tabel 5 data pada tegangan output tidak terlalu besar drop tegangan nya, nilai tegangan yang terukur rata-rata sebesar $6,1 \mathrm{~V}$.

Tabel 6. Nilai Output Converter Terhadap Kondisi Tanah Lembab (Berbeban)

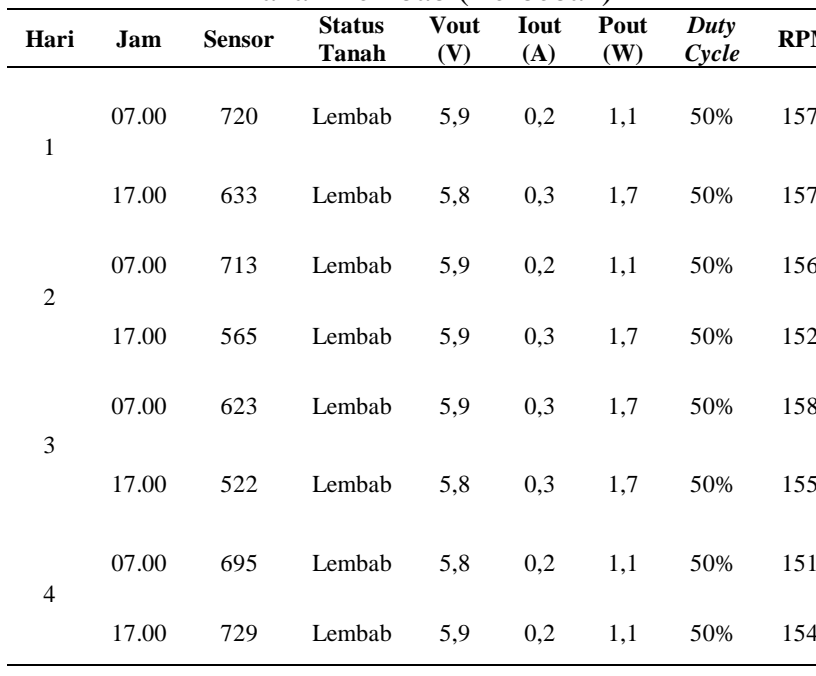

Pada keadaan berbeban di kondisi tanah lembab, sesuai dengan tabel 6 dapat dilihat bahwa nilai tegangan output sesuai dengan dutycycle yang telah di setting, nilai tegangan output nya rata-rata $5,59 \mathrm{~V}$ dengan nilai arus output rata-rata 0,28 A dengan daya output rata-rata $1,55 \mathrm{~W}$. Dan rata-rata kecepatan motor yaitu 1655 RPM.

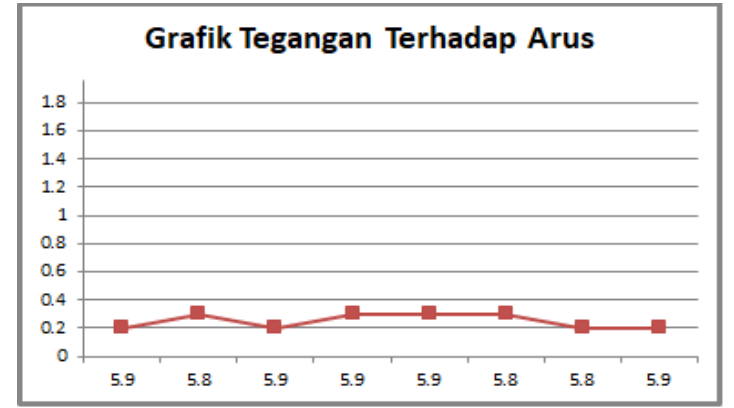

Gambar 10. Grafik Tegangan Teradap Arus Kondisi Lembab

Pada gambar 10 dapat kita lihat grafik tegangan terhadap arus yang mana nilai arus terendah bernilai sebesar 0, 26 A pada saat tegangan bernilai 5,6 Volt. Kemudian nilai arus tertinggi bernilai 0,3 A saat tegangan bernilai 5,48 Volt.

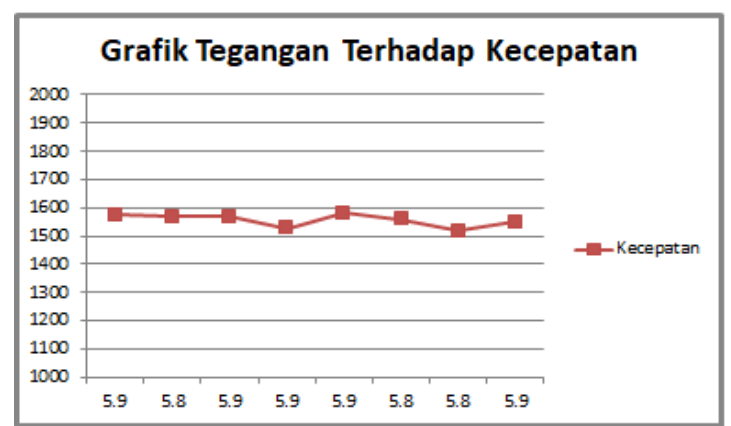

Gambar 11. Grafik Tegangan Terhadap Kecepatan Kondisi Lembab

Pada gambar 11 dapat kita lihat grafik yang menggambarkan tegangan terhadap kecepatan, yang mana nilai kecepatan motor bernilai rendah sebesar 1549,2 RPM dengan nilai tegangan 5,54 Volt. Sementara nilai kecepatan motor yang tertinggi bernilai sebesar 1780,6 RPM, kondisi ini terjadi pada saat nilai tegangan bernilai 5,6 Volt.

\section{E. Studi Kasus Keadaan Basah}

Pada pengujian ini diterapkan pada tanah yang intensitas air nya basah dengan asumsi nilai sensor 0 sampai 500, sehingga pada percobaan ini diperoleh hasil keluaran dari pembacaan sistem.

Tabel 7. Nilai Output Converter Terhadap Kondisi Tanah Basah (Tanpa Beban)

\begin{tabular}{cccccc}
${ }^{549}$ Hari & Jam & Sensor & Status Tanah & $\begin{array}{c}\text { Vin } \\
(\mathbf{V})\end{array}$ & $\begin{array}{c}\text { Vout } \\
(\mathbf{V})\end{array}$ \\
\hline \multirow{2}{*}{1} & 07.00 & 329 & Basah & 12 & 0 \\
& 17.00 & 476 & Basah & 12 & 0 \\
\multirow{2}{*}{2} & 07.00 & 447 & Basah & 12 & 0 \\
& 17.00 & 340 & Basah & 12 & 0 \\
\multirow{2}{*}{3} & 07.00 & 491 & Basah & 12 & 0 \\
& 17.00 & 351 & Basah & 12 & 0 \\
4 & 07.00 & 334 & Basah & 12 & 0 \\
& 17.00 & 360 & Basah & 12 & 0 \\
\hline
\end{tabular}




\section{Rancang Bangun Pengendali Sistem Pompa Otomatis Pada Penyiraman Tanaman Berbasis Sensor Kelembaban dengan Kendali Arduino}

Pada hasil pengukuran di kondisi tanah basah tanpa diberi beban menghasilkan tegangan output berkisar $5,85 \mathrm{~V}$. Tegangan yang terukur sangat jauh dari nilai tegangan suplai nya.

Tabel 8. Nilai Output Converter Terhadap Kondisi Tanah Basah (Berbeban)

\begin{tabular}{cccccc}
\hline Hari & Jam & Sensor & $\begin{array}{c}\text { Status } \\
\text { Tanah }\end{array}$ & $\begin{array}{c}\text { Vin } \\
(\mathbf{V})\end{array}$ & $\begin{array}{c}\text { Vout } \\
(\mathbf{V})\end{array}$ \\
\hline \multirow{2}{*}{1} & 07.00 & 339 & Basah & 12 & 0 \\
& 17.00 & 466 & Basah & 12 & 0 \\
2 & 07.00 & 445 & Basah & 12 & 0 \\
& 17.00 & 346 & Basah & 12 & 0 \\
3 & 07.00 & 481 & Basah & 12 & 0 \\
& 17.00 & 371 & Basah & 12 & 0 \\
4 & 07.00 & 324 & Basah & 12 & 0 \\
& 17.00 & 370 & Basah & 12 & 0 \\
\hline
\end{tabular}

Pada kondisi tanah basah dengan diberi beban maka tegangan output nya 0 Volt. Ini dikarenakan pada kondisi tanah basah, motor di setting agar tidak menyala sehingga tegangan yang dihasilkan 0 Volt. Karena pada kondisi tanah basah motor tidak perlu menyirami lagi. Ini terjadi dikarenakn kemungkinan kondisi cuaca sedang hujan atau persediaan air didalam tanah masih banyak.

F. Analisa Hasil Pengujian Berdasakan Studi Kasus Keseluruhan

Dari hasil uji tiap-tiap kasus kondisi tanah, dapat dianalisa bahwa efisiensi daya pada tiap-tiap kondisi berbeda. Setelah dihitung sesuai dengan persamaan 2.19, maka daya pada keadaan tertinggi yang di kalkulasikan

Tabel 9. Tabel Analisa Efisiensi Daya Buck

\begin{tabular}{ccc}
\multicolumn{3}{c}{ Converter } \\
\hline Pin (W) & $\begin{array}{c}\text { Pout } \\
(\mathbf{W})\end{array}$ & H \\
\hline 4,8 & 3,9 & $81 \%$ \\
\hline
\end{tabular}

\section{KESIMPULAN}

Adapun beberapa kesimpulan yang diperoleh dari penulisan skripsi ini yaitu perubahan tegangan yang dihasilkan pada buck converter dipengaruhi oleh duty cycle. Sehingga pada saat kondisi tanah yang dibaca oleh sensor kelembaban berubah, maka akan mengirimkan duty cycle yang berbeda sesuai dengan kondisi tanah yang dibaca, maka keluaran tegangan akan berbeda sehingga mempengaruhi kecepatan motor untuk berubah. Seperti pada saat kondisi tanah sangat kering, tegangan yang dihasilkan berkisar \pm 11,7 volt, dengan kecepatan putar motor \pm 3500 RPM. Akan berbeda pada saat kondisi tanah kering yang hanya menghasilkan tegangan \pm 9 volt dengan kecepatan putar motor \pm 2600 RPM. Dan begitu juga tegangan yang dihasilkan pada saat kondisi tanah lembab, tegangan nya \pm 6 volt dengan kecepatan putar motor pompa \pm 1600 RPM. Namun pada saat kondisi tanah badah, sistem tidak menghasilkan tegangan dikarenakan perintah pada saat kondisi basah adalah motor pompa mati atau off. Sehingga sesuai dengan validasi yang dilakukan dengan membandingkan data tegangan dan arus yang dihasilkan, rancang bangun pengendali sistem pompa otomatis pada penyiraman tanaman berbasis sensor kelembaban dengan kendali arduino berhasilkan di implementasikan dengan baik.

\section{DAFTAR PUSTAKA}

[1]. Alam, S., Tony, H., \& I. A. (2018). Rancang Bangun Sistem Penyiraman Otomatis Untuk Tanaman Berbasis Aruduino Dan Kelembaban Tanah, 44-57.

[2]. Azhari, F. W., \& Aswardi. (2020). Sistem Pengendalian Motor DC Menggunakan Buck Converter Berbasis Mikrokontroler ATmega 328, 352-364.

[3]. Caesar Pats Yahwe, I. L. (2016). RANCANG Bangun Prototype System Monitoring Kelembaban Tanah Melalui Sms Berdasarkan Hasil Penyiraman Tanaman "Studi Kasus Tanaman Cabai Dan Tomat", 97-110.

[4]. Erricson Zet Kafiar, E. K. (2018). Rancang Bangun Penyiram Tanaman Berbasis Arduino Uno Menggunakan Sensor Kelembaban YL-39 Dan YL-69, 267-276.

[5]. Fauzan Hadisyahputra, N. L. (2017). Perancangan Catu Daya Dengan Penambahan Panel Surya Pada Smart Traffic Light, 1-8.

[6]. Gede, C. P. (2014). Rancang Bangun Sistem Pengangkatan Air Menggunakan Motor AC dengan Sumber Listrik Tenaga Surya.

[7]. Hart, D. W. (2011). Power Electronics. New York: McGraw-Hill.

[8]. Hasan, F. H. (2017). Rancanng Bangun MPPT Dengan DC-DC Buck Converter Pada Panel Surya Dengan Beban Pompa Air DC.

[9]. Muhammad Fadhil, B. D. (2015). Rancang Bangun Prototype Alat Penyiram Otomatis denganSistem Timer RTC DS1307 Berbasis Mikrokontroler Atmega16 pada Tanaman Aeroponik, 37-43.

[10]. Sirait, C. Y., \& Matalata, H. (2018). Perancangan Boost Converter Dengan Ldr Sebagai Pengendali Sinyal Pwm Untuk Menaikan Tegangan Panel Surya, 39-44.

[11] Agung, Albertus. "Design And Implementation Of Wireless Sensor And Actuator For Plc Based Scada System In Standard Water Filtration Process." Patria Artha Technological Journal 2.1 (2018): 1-18

Copyright @2016 PROtek : Jurnal Ilmiah Teknik Elektro cc) (†) lisensi Creative Commons Attribution 4.0 EY NC SA International Licensi 